\title{
The functional basis of case systems and declension classes: \\ from Latin to Old French*
}

FRANS PLANK

\section{Abstract}

The development of the Old French (OF) system of one or two cases and three declensions from the Classical Latin system of six cases and five declensions, via Vulgar Latin (VL), cannot be accounted for without reference to the syntax and semantics/pragmatics of the central grammatical relations of subject, object, attribute. It is argued in this paper that many $V L / O F$ 'analogical' inflectional changes and re-distributions of nouns among existing or newly formed declension classes, changes that seem arbitrary from a purely morphological or phonological perspective, are determined by a general functional principle: overt relational distinctions are made (created or not abandoned) only if necessary in order to distinguish co-occurring term phrases and to identify their grammatical relation/semantic role, in so far as this is not possible on account of the pragmatic and semantic properties of these terms. This investigation also has implications with regard to the relationship between functionally based and grammaticalized relational encoding. Although the inflectional coding of each noun may be strictly grammaticalized rather than functionally variable, languages with declension classes do not a priori fall outside the scope of the functional principle; rather, it is this kind of nominal classification itself which has a functional rationale.

Although there exists considerable crosslinguistic variation concerning the encoding of such central grammatical term relations as (transitive, intransitive) subject, direct and indirect object, and nominal attribute in languages whose syntax is in fact based on genuine grammatical relations rather than on purely semantic (agent, patient, etc.) or pragmatic (topic, comment) concepts - this variation is in several respects neatly patterned rather than completely random. In the search for typological or even more general determinants of such patterns, functional, rather than 
formal, considerations of varying degrees of systematicity and explicitness have traditionally played a prominent role. In recent years, for example, a functional principle has been claimed (by Bernard Comrie, among others) to account for two kinds of patterns involving transitive $\left(S_{t}\right)$ and intransitive $\left(\mathrm{S}_{\mathrm{i}}\right)$ subject and direct object (DO) relations: (a) natural languages typically do not use three entirely different markers to encode $S_{i}, S_{t}$, and DO, but, more economically, get along with only two distinct markers; ${ }^{1}$ however, not all patterns of relational identification that are a priori imaginable are actually found (e.g. $S_{i} \neq S_{t}=D O$; cf. Comrie, 1975a; Bechert, 1979); (b) in a single language certain relations, especially DO, may be encoded variably (zero versus non-zero marking), depending on semantic and/or pragmatic term properties (such as definiteness, as in Uralic and Altaic languages; cf. Comrie, 1975b). In general, the functional principle (in the version of Comrie; cf. also Anderson, 1976; Martinet, 1979) asserts that systems of relational coding ought not be more wasteful with their resources than absolutely necessary to cope with the task of overtly distinguishing, in an otherwise arbitrary manner, those relational terms that co-occur in an actual (simple or complex) sentence. If there is only one term present, as in intransitive or in subject- or object-deprived transitive clauses (e.g. imperatives), there is no need to distinguish anything; hence $S_{i}$ ideally remains without a special marker, and a lone $\mathrm{DO}^{2}$ or a lone $S_{\mathrm{t}}$ may encode like an $S_{\mathrm{i}}$. With two-term clauses, it suffices for the purpose of distinction to overtly mark only one term, the $S_{t}$ (as, allegedly, in ergative systems ${ }^{3}$ ) or the DO (as in accusative systems). To mark both would be uneconomical; to mark none or to mark both identically would violate the basic functional distinctness requirement. But since in two-term configurations relational distinction is often possible already on semantic and/or contextual-pragmatic grounds (as, obviously, in sentences like Jones drank a pint of beer, but not in Jones hit Smith), it is functionally legitimate to confine the use of overtly distinctive markers to cases of actual emergency, e.g. to situations where a term occurs in a semantically or pragmatically unaccustomed relation (for example: $S_{t}$ is typically definite, DO typically indefinite [Keenan, 1976], hence DO is marked only if it happens to be definite itself).

It is hardly surprising that the functional principle in this general and unrestricted form - which, on the other hand, enhances its intuitive appeal - should face serious problems, both on the descriptive and the explanatory side. To mention only three of these less appealing aspects: overt DisTINCTION is not the only task of relational encoding; it is of even greater communicative importance that the underlying semantic roles (agent, patient, experiencer, etc.) be uniquely IDENTIFIABLE from overt relational coding (cf. Bechert, 1979; Dik, 1978; Plank, 1979a). The safest 
way of guaranteeing identifiability would be a syntagmatically invariable, if functionally uneconomical, bi-unique mapping between semantic roles and grammatical relations; and in fact the maintenance of semantic transparency often interferes with the antagonistic force of functional parsimony (Plank, 1978b). Secondly, it seems that the distinction of nominal attributes (A) from their head terms is functionally more important than the $S_{1}-D O$ distinction, contrary to the assumptions of many functionalists (cf. Plank, 1979a). Thirdly, the means available for relational coding are in many languages not utilized according to functional necessities, but rather on a stable, grammaticalized basis. DOs, for example, often receive an accusative marker irrespective of whether or not they are typical instances of this relation on account of their semanticreferential nature; or DOs are encoded identically regardless of the presence or absence of an $S_{t}$.

Despite such eventual qualifications or more thorough modifications, functional considerations of this kind can still contribute considerably to our understanding of the organization of grammatical relations, of their typological patterning, and their diachronic developments. The present paper is concerned with this latter aspect; its aim is to demonstrate that a number of otherwise arbitrary phenomena in the development of the Old French (OF) case system and declension classes from Classical Latin (CL) via Vulgar Latin (VL) - especially developments that can be subsumed under the rubric of analogical change - have a rather natural functional motivation. This functional basis is supplied in a fairly straightforward manner as far as the clausal S and DO relations are concerned; but some developments of the adnominal A relation also lend themselves to a functional interpretation, albeit of a more elaborate nature. Within a wider perspective, the present investigation attempts to contribute to a GENERAL theory of coding change, the indispensible explanatory framework for accounts of restructurings and reductions of languageparticular synthetic coding systems. I hope to show that functional requirements are particularly suitable guidelines of morpho-syntactic change in periods of marked instability such as transitions from synthetic to analytical relational encoding.

Part of the reduction of the (maximally) 6-case system of CL to the 2-3case system of VL and, finally, the 1-2-case system of OF can be accounted for in phonological terms. This is not to say, of course, that a statement of the pertinent phonological rules already explains this analytic drift, in particular since the still common view that phonetic attrition of (unstressed) inflectional endings causes morphological and syntactic change is as obsolete with respect to the Romance as to the Germanic languages. But we are presently interested not so much in the causes and 
effects of phonological change affecting morphological paradigms, but rather in changes of declensional paradigms accompanied by redistributions of substantives inflected according to these paradigms. The transformation of the five $\mathrm{CL}$ into the three $\mathrm{VL}$ and three (i.e. three per gender) OF declension classes, with the concomitant loss of the neuter gender, involves a number of such processes. Although its class membership initially remained relatively constant, the $\mathrm{CL}$ and $\mathrm{VL}$ third declension deserves closer scrutiny first, because of its noticeable tendency towards massive intraparadigmatic levelling already observable in CL and, sporadically, even earlier.

Although other criteria for subclassification are more familiar from Latin grammars, it is more appropriate for the present purpose to arrange $\mathrm{CL}$ third declension substantives in three groups, according to the two criteria of variable/invariable paradigmatic syllable number and presence/absence of paradigmatic stress alternation: into parisyllabics without stress alternation (1a), imparisyllabics without stress alternation (1b), and imparisyllabics with stress alternation (1c): ${ }^{4}$

(1) a. pater, patris 'father' Nominative Singular, Genitive Singular; finis, finis 'end'; mare, maris 'sea'; vulpes, vulpis 'fox'; caro, carnis 'flesh'.

b. mens, mentis 'mind'; sors, sortis 'lot'; mons, montis 'mountain'; rex, regis 'king'; grus, gruis 'crane'.

c. aéstas, aestátis 'summer'; léo, leónis 'lion'; vírtus, virtútis 'virtue'; dólor, dolóris 'pain'; ánimal, animális 'living being'.

In the present context distinctions other than those between Nominative Singular (the S case) and Genitive Singular (the A case) are disregarded; at the stage of VL the Genitive Plural is still distinctively encoded vis $a$ vis the Nominative Accusative Plural, and questions of the NominativeAccusative distinction will be dealt with later. On the whole, the first group (1a), especially its vowel stems ( finis etc.), served as a model for the entire declension class since both other groups, beginning in pre-CL (cf. occasional early Nominative Singular forms like mentis, sortis; and with already standardized analogical -is in CL, mensis 'month', canis 'dog', navis 'ship'), and on a large scale in VL, show intraparadigmatic levelling leading to paradigmatic uniformity on the criteria of syllable number and stress pattern: in VL, all paradigmatic forms of third declension substantives typically are parisyllabic and lack stress alternation. ${ }^{5}$ This target conforms very well with a general principle dominating drifts towards analyticity, viz. Sapir's (1921) 'drift toward the invariable word'. The specific methods of achieving this target in VL are instructive from a formal and a functional viewpoint. If such paradigmatic distinctions 
between Nominative Singular and Genitive Singular as shown in (1b) and (lc) are neutralized, one would of course wish to be able to predict the direction of levelling - to predict, that is, which paradigmatic form is likely to survive as the sole representative of an erstwhile manifest morphological opposition. Often this is claimed to be a matter of markedness: the less marked (here presumably the Nominative) rather than the more marked (the Genitive) form ought to win the day. The case at issue turns out to be more complicated, though: different substantives level in different directions. Usually, the Genitive Singular ousts the Nominative Singular form (2a), but in some instances parisyllabicity and fixed stress are also accomplished the other way round (2b). (For the sake of simplicity, VL phonological developments are being disregarded.)
a. CL mors, mortis
mons, montis
flos, floris
mens, mentis
dens, dentis
grus, gruis
hospes, hospitis
aéstas, aestátis
léo, leónis
vírtus, virtútis
dólor, dolóris

b. CL sanguis, sanguinis

héres, herédis
VL mortis, mortis 'death' montis, montis 'mountain'

floris, floris 'flower' mentis, mentis 'mind' dentis, dentis 'tooth' gruis, gruis 'crane'

(h)ospitis, (h)ospitis 'guest' aestátis, aestátis 'summer' leónis, leónis 'lion' virtútis, virtútis 'virtue' dolóris, dolóris 'pain'

VL sanguis, sanguis 'blood' héres, héris 'heir'

One familiar markedness criterion could play a marginal role, viz frequency of use. On account of their lexical semantics (/-human/, or /-animate/), some of the substantives concerned are perhaps not used very often in $S_{(t)}$ function, which could contribute to rendering their Nominative form obsolete. (An analogous issue is taken up again below.) But a much more important factor would seem to be the tendency of the language, in its drift towards analyticity, to reduce stem and desinential allomorphy. Stem allomorphy in the substantives under (2a) could have been avoided, of course, by generalizing the Nominative form (mors, mors; leo, leo etc.), just as in (2b); but this strategy would have created two other conflicts. The final consonant of the Nominative form often does not directly reflect the basic stem variant (mort-, mont-, flor-, hospit- etc.), ${ }^{6}$ and allomorphic variation would again be the result (cf. derivational forms such as mortuus, mortalis, mentalis, hospitium). Secondly, generalization of the Nominative Singular form would increase overall desinential 
allomorphy by creating new idiosyncratic paradigms that would not fit in at all with existing declensional patterns, especially with that of the third declension vowel stems (finis, finis; vulpes, vulpis). On both these counts, the Genitive Singular form fares much better: it has the basic stem-final consonant, and thus preserves the overall unity of the stem; and it has a desinence conforming to a general inflectional pattern. The latter factor was probably responsible for the different direction of levelling in (2b): the Nominative Singular of these substantives already looks like it could be a member of a general declensional pattern - that of the third declension vowel stems; ${ }^{7}$ and this may have been decisive, even though the integrity of the stems (sanguin-, hered-) was thus violated.

What is of greater functional interest is that a number of third declension substantives steadfastly resist any intraparadigmatic levelling of this kind: nearly all substantives that denote persons (3a), and masculine-turned former neuters without stress alternation $(3 \mathrm{~b}):{ }^{8}$

a. CL, (early) VL homo, hominis 'man'
comes, comitis 'companion, count'
imperátor, imperatóris 'emperor'
pástor, pastóris 'shepherd'
cántor, cantóris 'singer'
látro, latrónis 'robber'
népos, nepótis 'nephew'
infans, infántis 'child'
sóror, soróris 'sister'
tempus, temporis 'time'
opus, operis 'work'
pectus, pectoris 'breast'
caput, capitis 'head'
cor, cordis 'heart'
b.
fel, fellis 'gall'
nomen, nominis 'name'

Although they are parisyllabic and without stress alternation to begin with, / human/ substantives from group (1a) such as pater, frater could also seem to belong here in so far as they continue to clearly distinguish Nominative Singular and Genitive Singular. The obvious problem now is to determine whether paradigmatic levelling is inhibited randomly, on purely formal morphological grounds, or for some deeper syntactic or semantic reason. It has occasionally been suggested (cf. e.g. Rheinfelder, 1967: 13; Pope, 1952: 309) that the paradigmatic development of these third declension substantives is not completely accidental, but follows 
from the structure of their respective (sub-)paradigms and/or the likelihood of their use in particular paradigmatic forms. The Nominative Singular and the Accusative Singular of the former neuters (3b) were formally identical, and this usage of one form for two functions is claimed to have prevented its replacement by a mono-functional paradigmatic form such as the Genitive. The original Nominative Singular is thus said to be paradigmatically supported by the homophonous Accusative Singular. The Nominative Singular of the / + human/ substantives (3a) is also paradigmatically supported; in this case by the homophonous vocative. ${ }^{9}$ Only substantives denoting persons are likely to be used in the vocative; hence others (such as those in 2) cannot count on support from this case form. Although the argument based on semantically determined potentialities of occurrence is certainly attractive (and will also figure in the functional account to follow), the explanatory value of the notion of paradigmatic support per se appears to be doubtful. If the neuter gender had already ceased to exist as a formal category important for the delimitation of declensional paradigms, what should prevent the former neuters from joining the formally more regular declensional paradigm with the characteristic desinence -is? Would it not be more natural, in the interest of greater overall paradigmatic uniformity, if both nominative and vocative of the personal substantive acquired the regular -is forms, rather than idiosyncratically resisting the general levelling tendency and thus creating separate paradigms? It would be rash to abandon the concept of paradigmatic support on account of its eventual failure to answer such questions; its role in determining paradigmatic change could only be evaluated adequately in confrontation with more extensive crosslinguistic evidence. For the data at hand, there is an alternative, or perhaps complementary, explanation available; and this requires a closer look at some synchronic and diachronic conditions on the encoding of A's.

The formal conflation of nominative and genitive in substantival paradigms increases the risk of relational ambiguity. Without a distinctive genitive case, A's are potentially no longer uniquely identifiable, especially in a language such as $\mathrm{CL}$ or VL where substantives alone, unaccompanied by inflectionally perhaps more distinctive adjectives or determiners, may constitute a complete term phrase. I have argued elsewhere (Plank, 1978a; 1979a) that the constraint against paradigmatically non-distinctive A encoding is universally much stronger than in $\mathrm{S}_{\mathrm{t}}-\mathrm{DO}$ configurations. With lexically governed relations (such as S and DO) the likelihood is that identification is possible even without overt distinction, on account of semantic and pragmatic probabilities determined by the governing lexical item, whereas with constructionally governed relations (such as A) identifiability usually presupposes overt distinction. Now, case syncretism 
need not amount to coding syncretism, since case inflection is but one of the relational coding devices available to natural languages; alternative or complementary devices are agreement/cross-reference between S/DO and predicate, ${ }^{10}$ or between $\mathrm{A}$ and its head ('for Jesus Christ his sake'), adpositions, and relationally distinctive constituent order. The diachronic generalization seems empirically well motivated (for the evidence, see Plank, 1979a) that case syncretism affecting the A form, especially vis $a$ vis the $\mathrm{S}$ form, ${ }^{11}$ has to be avoided unless a language has already developed reliable other means (analytic or synthetic ones) to tell an A from its head.

The inflectional and syntactic developments from CL to OF fit in rather well with this hypothesis. According to Gildersleeve and Lodge (1895: 430-1), constituent order was not entirely free in attributive constructions even in early Latin; they note a tendency for the genitival A, as opposed to the adnominal adjective, to follow its head. But this assumption is rather controversial (cf. Hofmann, 1965: 408-9, with further references); linear order is certainly no absolutely reliable indicator of A-hood in CL, nor presumably at the later stage where paradigmatic levelling in the third declension came to a climax. However, another analytical coding device, viz. the prepositions ad (especially common in Gallo-Roman) and de (which only later made its way as the standard French A marker), and also, in partitive constructions, ex (cf. 4), were competing with synthetic genitives of all declensions already in $\mathrm{CL}$, and were steadily gaining ground from the first century A.D. onwards, chronologically certainty prior to the onset of large-scale Nominative Singular - Genitive Singular levelling. ${ }^{12}$

(4) a. navis ad illum hominem 'the ship of that man'; hic requiiscunt membra ad duus fratres Gallo et Fidencio qui fuerunt fili Magno 'here are buried the remains of the two brothers G. and F., who were the sons of M.' (Gallo-Roman inscription, sixth/seventh century.)

b. Filuminus tonsor de circum ' $F$. barber of the circus' (Roman inscription, fourth/fifth century; with de governing the Acc. instead of the Ablative, as in CL); filia de rege 'daughter of the king'.

c. unus ex/de multis 'one of many'.

But prepositional encoding of A did not replace synthetic A's in a wholesale manner; the late Latin dialects (cf. especially Dardel, 1964) continued to use a general oblique case ${ }^{13}$ one of whose functions is to encode A's:

(5) fili Magno (occurring in the same sentence as an A with ad; cf. 4a); 
domus fratre 'house of the brother'; haec muneri origo 'the origin of this gift'; in curte duci 'in the court of the leader';

and by this strategy the A could also be encoded differently from a nominative $\mathrm{S}$ (in $\mathrm{CL}$ : frater, munus, dux; after VL levelling: fratris, muneris, ducis), even after Nominative Singular - Genitive Singular levelling in the third declension. These particular developments and the general observation that important case distinctions are not given up unless this loss can already be compensated for by alternative coding devices, could incline one to believe that an inflectional distinction of A's was indeed becoming superfluous in VL. If further maintenance of a distinctive genitive case thus constituted a functionally more and more redundant morphological complication, why do certain substantives of the third declension like those listed in (3) still refuse to abandon it, even though they could easily follow the example of the levelling members of the same declension class?

Let us consider the semantic structure of attributive genitive constructions. In CL, the grammatical $\mathrm{A}$ relation encoded by the genitive case expresses various semantic relations such as material, quantity measured, value, possessor, temporal/local point of reference, and, in nominalizations, those semantic relations otherwise underlying subjects and objects (cf. Hofmann, 1965: 50-77). Interestingly, the drift towards analytic encoding of $\mathrm{A}$ is sensitive to such semantic distinctions (cf. Väänänen, 1956). It is with partitive relations that the synthetic genitive is first rivalled and then replaced by prepositional constructions (especially with $d e$ ), whereas inflectionally encoded possessive relations defend themselves against the intrusion of analytic devices most successfully. The evidence available to me, essentially based on Indo-European languages, is as yet too scant to justify universal generalizations, but it nevertheless seems that this is not a Romance idiosyncracy: in transitions from synthetic to analytic encoding, it is possessive relations of the whole variety of semantic relations underlying attributive constructions that remain longest within the synthetic domain of case inflection and perhaps agreement/crossreference.

To a considerable extent VL genitives thus denoted possessors and their head terms possessions. Prototypical possessors can conveniently be characterized in semantic terms: animates and preferably persons are most likely to be attributed the capability of possessing something, and, unless they are seen as holding a quasi-possessive kinship relation, persons ought to be least likely to be possessed. In syntactic terms: substantives with the lexical feature / + human/are more predestined than any others to assume the grammatical A relation encoded by the genitive. The less 
restricted class of prototypical possessions is perhaps less easily characterized semantically; but at least there are inalienable possessions such as relatives $(/+$ human $/)$, body parts, other constituent parts (e.g. wheels of a car, name of an individual), and other entities of an inherently relational nature (e.g. top of a hill, time setting of an event, neighbours or enemies of someone, etc.), that naturally fall under this heading. Syntactically, substantives with these features are most liable to be construed as head terms of a genitival A relation. Now these criteria for prototypical genitival A's and their heads single out exactly those third declension substantives that resist paradigmatic levelling in VL: those denoting persons, i.e. potential possessors ( $3 a)$, and the former neuters many of whom denote typical (concrete or abstract) inalienable possessions ( $3 b$ ). It is true, the latter class is semantically somewhat more heterogeneous, but the relatively high percentage of appropriate substantives among these CL third declension neuters is nevertheless striking - further pertinent examples could without much difficulty be added to the list given under (3b): fémur, fémoris 'thigh', iécur, iécoris (with variants iecinoris, iecineris, iocineris) 'liver', gúttur, gútturis 'throat', crus, cruris 'leg', córpus, córporis 'body', oss, óris 'mouth', os, ossis 'bone', cadáver, cadáveris 'dead body'. It is thus understandable from the functional point of view that both these types of substantives with a propensity to the possessor and possession roles respectively are able to prevent a paradigmatic change that would deprive them of the possibility to overtly distinguish themselves from other relations co-present in actual sentences. In particular, a typically 'possessing' substantive ought to be capable of detaching itself from its head constituent, and vice versa; and this is accomplished most conveniently, given the transitory state of the language at issue, if both possessor and possession terms retain paradigmatic forms with a distinctive genitive case. For substantives that on account of their inherent semantic nature are less likely to enter possessive relationships in either of the opposite semantic roles, on the other hand, it is hardly worth while to resist paradigmatic simplifications for the sole purpose of preserving a relatively useless distinctive genitive form.

The functional principle in its versions that were alluded to at the beginning of this paper makes still another prediction: Relational coding ought to be made use of economically in the sense that semantically/pragmatically 'normal', expected relational occurrences of terms need overt marking less badly than 'non-normal', unexpected ones. (Recall the definite/indefinite DO example.) But we just argued that it is normal for persons to play the role of possessor - syntactically: to be construed as A's - and that this very semantic affinity necessitates distinctive coding resources. It thus looks as if the encoding of $A$ 
expressing prototypical possessors would have to meet two contradictory requirements here: the likelihood of persons being possessors makes overt distinguishability mandatory, and the semantic expectedness of this particular relational use of / human/ substantives ought to make overt distinctive marking rather dispensible. The contradiction is more apparent than real, however, for it must not be overlooked that A's share many semantic and pragmatic properties with another grammatical relation, that of S. The universally typical subject properties have recently been assembled by Keenan (1976). ${ }^{14}$ Semantically, S's, and especially $S_{t}$ 's, are preferably agents, and agenthood is prototypically attributed to persons. Pragmatically, $S_{1}$ as a rule is the unmarked topic of a predication, which accounts for its highly referential status. Although there is as yet no comparable survey of attribute properties available, the semantic affinity between agenthood and possessorship is intuitively obvious; and from a preliminary analysis of a sample of various kinds of contemporary written English and German texts (mostly dialogues) I conclude that the vast majority of A's (more than $90 \%$ in fact) is also highly referential, i.e. definite rather than indefinite. Disregarding S-less sentences, the actual occurrence of an $\mathrm{A}$ presupposes the simultaneous presence of an $\mathrm{S}$ although my English and German data suggest that A's rather tend to modify relational terms other than $\mathrm{S}_{\mathrm{t}}$. This means that in sentences with an $A$, there are at least two term phrases with potentially very similar semantic and pragmatic properties, and although on account of these properties it is natural for terms with the features / + human, +definite/ to assume the $A$ relation, they could function as $S$ just as naturally. Dispensing with clear overt marking in this situation would thus increase the risk of relational confusion. If relationally natural, 'normal' terms can remain unmarked for reasons of functional parsimony, $S$ and DO appear to have priority over $\mathrm{A}$.

It ought to be clear that diachronic functional explanations as attempted here cannot establish exceptionless 'laws' of paradigmatic change even in the VL third declension, some substantives in fact have undergone paradigmatic levelling although they belong among the prototypical possessors/possessions (cf. mens, dens, hospes in 2a). On the whole, this kind of explanation is the more apposite and promising, the better formal (declension) classes match with semantic classes. The third CL/VL declension was not entirely homogeneous semantically, but it contained sub-classes of masculines and (former) neuters with common semantic denominators, and this helped functional tendencies not to abandon certain relational distinctions in their paradigms to a victory over the strong antagonistic force of paradigmatic simplification. Originally, the functional principle was intended to provide a rationale for synchronic 
(language-particular) and panchronic (crosslinguistic) variability in the encoding of grammatical relations, and functionally based coding was opposed to grammaticalized, functionally invariable language-particular coding. But in the diachronic dimension functional and grammaticalized coding are not necessarily independent of, and opposed to, one another. Functional considerations can play a role in creating and preserving paradigmatic variability and in re-distributing nouns among paradigmatic classes according to semantic criteria, and may thus be responsible for the particular structure of newly grammaticalized coding paradigms. The repercussions in OF of the VL developments discussed so far once more emphasize the import of semantic factors for coding change.

The tendency in VL and in the early Romance dialects was to inflectionally encode only possessive A's, and, consequently, to retain a distinctive (third declension) genitive case only with typical possessor and possession substantives. Even this functionally reasonable genitive, after a transitory stage with three cases (Nominative, Accusative, and Genitive/Dative; cf. Dardel, 1964), soon falls a victim to the further reduction of the case system - an interesting development in comparison with the analytic drift in English, where the genitive proved the most resistant nominal case. Prepositional encoding of non-possessive A's had already been predominant quite early, but this differential treatment of typically possessive, i.e. personal, and other substantives in VL helped to establish in OF a more general classification of substantives on a semantic basis, independent of former paradigmatic affiliations. Only substantives denoting persons, and especially proper names, titles, and kinship terms, were able to occur, in their oblique form, in OF prepositionless attributive constructions of the following types:

(6) a. fil maistre Henri 'son of master H.'; la mort Rollant 'the death of R.'; li serf sum pedre 'the servants of his father'; la fille le roi 'the daughter of the king'; le chienet sa niece 'the little dog of his niece'.

b. la roi fille 'the king's daughter'; la Dieu merci 'God's mercy'; le Carlon messagier 'C.'s messenger'.

Non-personal substantives obligatorily had to rely on prepositions $(d e, a)$ if used as A's. ${ }^{15}$ That this pattern directly continues, and generalizes, VL synthetic possessive A constructions is also attested to by a further requirement on these OF prepositionless A's, which mirrors the prototypical possessor properties of A mentioned above: they have to be definite (specific reference), and are usually in the singular: ${ }^{16}$

(7) a. l'amor mon pere 'love of my father', but: l'amor d'un pere 'love of a father'. 
b. mestres Clamadeu 'the master of C.', but: li mestres des chevaliers 'the master of the cavaliers (of a group of cavaliers)'.

Obviously, these constructions do not violate the distinctness constraint on A's, since at this stage constituent order is already relationally significant, which identifies the second of two adjacent, or nearly adjacent (cf. Caÿn, qui freres fu Abel 'C., who was the brother of A.'), term phrases as an A. The pattern with A preceding its head (6b) was less common in $\mathrm{OF}$, and largely disappeared in the eleventh century; but even here the A can clearly be told from the head since preceding A's as a rule lack a determiner. To sum up: we already observed in VL the roots of a distinction in the encoding of different types of $\mathrm{A}$; in $\mathrm{OF}$, this dichotomous coding pattern that involved a limited class of substantives favouring inflectional A encoding on functional grounds, was generalized and led to an entirely semantic noun classification, replacing a semantically largely arbitrary classification according to declension classes. The new class system was relevant not only for the purposes of A encoding, but also for that of indirect objects, which in OF likewise may lack a preposition if denoting persons (e.g. mon pere venist requerre icest afere 'il vint demander cela à mon père'; cf. Wartburg, 1943: 69; Foulet, 1972: 27-31). That indirect objects should share this feature of variable coding contingent on semantic criteria is perhaps no coincidence; indirect objects typically denote animates and especially humans, i.e. the lexical entries that on account of their inherent semantics are likely to assume the indirect object relation, are the same that show a marked propensity to agenthood (S relation) and possessorship (A relation). ${ }^{17}$

A brief digression on a close parallel to the OF developments from the history of English is instructive, since this similarity confirms the hypothesis that under the circumstances of transitions from synthetic to analytic coding the coding devices for attributive constructions tend to treat nouns differently according to their semantic/pragmatic affinity to the possessor and possession roles (cf. also Plank, 1979a). Although the genitive case in English is a diachronically quite stable synthetic relic, ${ }^{18}$ there occasionally occurred uninflected, prepositionless A's:

(8) a. Early Middle English (Orrmulum; data from Lehnert, 1953): hiss azhenn broper wif, inn hiss Faderr bosemm, pe kyng sonne, pe leffdiz lac, off twellf winnterr elde, inn hiss moderr wambe, inn aniz kinne sinne.

b. Early Modern English and later dialects (cf. Ekwall, 1913): the emperoure moder, the Frenche Kyng dowthur, Patrik house, The Abbot of Redyng place, Master Wyllde bequest, the oulde goose fether; Thomas Gillman wiff. 
The formerly free order in attributive constructions had already been stabilized, so that an uninflected noun preceding another noun could be identified as an A. What is particularly interesting in the present context, however, is that A's and heads encoded by order rather than inflection or preposition fall into semantically natural classes: the heads are preferably inherently relational nouns (i.e. typical possessions), and the A's preferably denote persons or at least animates, and are definite and in the singular (i.e. typical possessors) - exactly the same configuration that we encountered in VL and OF as the point of reference for functionally prevented or induced paradigmatic change.

After an interpretation of A-related coding changes in functional terms, we can now turn to developments of the clausal relations $S$ and DO up to that period of OF (twelfth - thirteenth century) where there still existed a (maximally) two-case system. These two cases will be referred to as Nominative and Accusative - for typological reasons: the Accusative encodes DO, and the Nominative both $S_{i}$ and $S_{i}$; and for languageparticular historical reasons: on formal evidence (cf. Rheinfelder, 1967: 18), the Latin Accusative rather than another oblique case can be identified as the historical source of the general oblique form (Accusative) in the Romance languages. How many declension classes are there initially in OF, and how do they compare with those of VL? Different grammars give slightly different answers to the first question: six formal declension classes, or only three, but each subdivided into a masculine and a feminine paradigm (for the basic data, see Rheinfelder, 1967: 19-48; Pope, 1952: 308-316). I adopt this latter way of arrangement, and in the following refer to first, second and third masculine and feminine declensions in early $\mathrm{OF}$, in order to underline the influential organizing principle of gender. ${ }^{19}$ These three (or six) paradigm classes have still much in common, though: with a few exceptions, the Accusative Plural desinence is everywhere $-s$ or $-z$ ([ts]), and the Accusative Singular desinence everywhere $-\phi$. The choice of Nominative Singular and Nominative Plural desinences correlates to a considerable extent with gender: feminines usually have $-\emptyset$ in the Singular, and $-s /-z$ in the Plural, masculines $-s /-z$ in the Singular, and $-\varphi$ in the Plural. With the important exception of the third masculine and feminine declensions, which in addition have stem alternations, neither masculines nor feminines thus have more than two distinct paradigmatic forms; but whereas masculines tend to differentiate Nominative and Accusative for each number, and Singular and Plural for each case (Singular: Nominative $-s /-z$, Accusative $-\phi$; Plural: Nominative $-\phi$, Accusative $-s /-z$ ), feminines tend to conflate Nominative and Accusative and to distinguish only Singular and Plural of this single case form. A few further morphological and phonological factors have to be taken into consideration, though; and 
these justify setting up three distinct declension classes per gender. Some characteristic properties of these classes as well as redistributions of substantives among these classes via à vis VL are, I contend, conditioned by functional principles of paradigmatic change.

The first masculine and feminine classes are the most comprehensive ones in OF; their respective sources are the VL second (all masculine) and first (all feminine, with a few exceptions that will be dealt with immediately) declensions, whose members undergo only minor phonological changes (reductions of unstressed desinential vowels):

(9) a. VL muros, muro, muri, muros Nominative, Accusative Singular, Nominative, Accusative Plural $>$ OF murs, mur, mur, murs 'wall' (masculine).

b. VL porta, porta, porte (portas), ${ }^{20}$ portas $>$ OF porte, porte, portes, portes 'door' (feminine).

The former $\mathrm{CL}$ second declension neuters had already been formally assimilated to the masculines of this class in VL (e.g. CL vinum Singular, vina Plural > VL vinus, vini; CL castellum, castella > VL castellus, castelli), but a number of substantives from other sources also joined the first masculine class and had to acquire suitable new Nominative Plural forms analogically:

a. VL second declension (CL fourth) cantus/canti > OF chant 'songs' Nominative Plural.

b. VL third declension canes/cani > OF chien 'dogs' Nominative Plural; leones > lion 'lions' Nominative Plural.

The hallmark of the OF second masculine declension is the initial absence of a Nominative-Accusative distinction in the singular:

(11) a. gendre, gendre, gendre, gendres 'son-in-law'.

b. pedre, pedre, pedre, pedres 'father'.

This small class essentially inherits the masculines in -er from the CL/VL second declension (11a), and the CL/VL third declension substantives in -ter, with an analogically restructured Nominative Plural without $-s$ (1lb). Specific problems connected with the OF second feminine class, whose members, unlike those of the first feminine class, do not end in - $e$ but may have optional Nominative Singular forms with $-s /-z$ (e.g. $f i n(s)$ 'end', parz/part 'part' main(s) 'hand'), are less relevant for the following discussion. After this general outline I wish to focus attention on three 
particular developments within this part of the OF class and case system.

Firstly, the former neuters in CL/VL -us, -oris, which were among the VL substantives that had resisted the levelling of Nominative and Genitive Singular (cf. 3b), also joined the OF first masculine declension. They constitute a peculiar sub-group, however, in so far as they end up as indeclinables:

VL tempos, tempos, tempora/tempos, tempora/tempos $>$ OF tens, tens, tens, tens 'time' (similarly: cors 'body', piz 'breast' < pectus, ues 'need' < opus, etc.).

Since they were formerly neuters, they were traditionally accustomed to the lack of a Nominative-Accusative distinction. But on the other hand, the clear Nominative-Accusative distinction is so pervasive a trait of OF masculines that one could have expected these particular substantives also to have tried to find a way of conforming to this general formal pattern. Analogical loss of final $-s$ in the Accusative Singular and Nominative Plural could have been a possibility (cors, cor on the pattern of murs, mur in 9a), or perhaps the original stem variants (tempos, tempor-) could have been exploited to shape distinctive Nominative and Accusative forms. But nothing along these lines interfered with regular phonological changes that rendered these substantives indeclinable. Perhaps the need to distinguish $\mathrm{S}$ and DO cases in these instances was not urgent enough to justify such analogical restructuring?

Secondly, a semantically and morphologically homogeneous sub-group of the VL first declension joins the OF first masculine class: substantives such as propheta, poeta, papa, eremita, which were exceptional in VL in so far as their natural gender (masculine) tended to override the grammatical gender (feminine) characteristic of this declension. A priori, one could imagine at least two alternative developments of these substantives. They could in principle have joined the OF second masculine declension, although this is perhaps less likely on formal grounds (the second masculine class has the characteristic ending -re preceded by consonant, which is quite dissimilar to that of the nouns in question); and the first masculine class moreover is the most comprehensive, and hence potentially most attractive class anyway. Or they could have joined the first feminine class, despite their natural gender - and in fact these substantives do have grammatically feminine variants in OF (la profete/li profetes, la pape/li papes). Notice that the important distinctive feature of the first masculine declension is that it enables these substantives to clearly distinguish S and DO inflectionally: 
profetes, profete, profete, profetes

The results of both these developments are functionally highly desirable. Let us consider how a functional principle can be instrumental in cutting down on the alternatives of paradigmatic change in these cases. Since linear constituent order was still relatively free on the clausal level in OF (cf. Foulet, 1972: 306-332; Gamillscheg, 1957: 546-556), other resources for distinctive $S$ and DO encoding were rather useful, especially for such nouns that could potentially assume opposite semantic roles such as agent - patient or experiencer - stimulus. Partly, determiners could fulfil this task, at least for masculines:
a. definite: li-lo/le Nominative-Accusative Singular, li-les Nominative-Accusative Plural
b. indefinite: uns-un, (li) un-(les) uns;

but determiners were not at all employed as regularly with almost every noun as in Modern French (cf. Foulet, 1972: 45-83), and thus were anything but an absolutely reliable coding device. On account of their inherent lexical semantics, nouns can be arranged on a scale of potential agentivity (or, equivalently, animacy or individuality - cf. Silverstein, 1976; Dixon, 1979; Comrie, 1978; Plank, 1979a), and on this scale personal pronouns (especially first and second person), proper names, and nouns designating animates and especially humans rank highest. Irrespective of specific requirements of particular predicates, these nouns are typical representatives of agent and experiencer roles, whereas the probability is much lower that nouns designating inanimates or abstract concepts, which rank lowest on the agentivity hierarchy, occur in these roles; they are typically limited to such roles as patient or stimulus. If there is hardly a chance for a noun to fill the agent or experiencer slot of the role frame of a predicate, distinct paradigmatic forms to encode the S and DO relations are dispensible luxury (cf. the Indo-European neuters). A high degree of inherent agentivity, on the other hand, also enhances relational versatility: with a great number of two-place predicates like 'like', 'hit', 'kill', 'love', 'see' etc., the same noun may once be an agent/experiencer, once a patient/stimulus. It is thus functionally expedient for them to be able to overtly indicate which particular role they happen to play each time they occur.

It is not surprising in this light that OF indeclinable former neuters such as those listed in (12) made no particular effort to analogically acquire distinct Nominative and Accusative forms. They have previously been characterized as typical 'possessions' (which feature was claimed to have 
inhibited Nominative-Genitive levelling in VL), and as such they are automatically low on the agentivity scale, and on the whole rather unlikely to occur as $S_{t}$. Their membership in an OF masculine declension class at least enables them to resort to a distinctive determiner, if relational distinction is at all necessary. For the VL first declension substantives of the propheta type (cf. 13) the association with the OF first masculine class was a functionally reasonable choice, since only this paradigm provides systematically distinctive $\mathrm{S}$ and DO desinences - and the high position on the agentivity scale of these nouns, all of which denote persons, predicts that such distinctions are in fact going to be needed. The OF second feminine declension did have distinctive Nominative Singular forms with $-s$, but only as occasional variants, restricted moreover to the central dialects (cf. Rheinfelder, 1967: 30); this class, furthermore, contained mostly abstract substantives, which ought to have minimized its force of attraction upon personal substantives. What is still somewhat surprising in the light of this functional account is that these substantives continue to have first feminine declension variants (la pape Nominative Accusative Singular) - the more so as there is a marked tendency already in VL to synchronize natural and grammatical gender. ${ }^{21}$ Only detailed philological evidence could help clarify whether in situations where S-DO distinction is desirable, first masculine inflection was probably preferred. The distribution suggested by the functional principle would be that li papes is preferably used for $S_{t}$ co-occurring with animate (and perhaps definite) $\mathrm{DO}$, and la pape for $\mathrm{S}_{\mathrm{i}}$ and perhaps also DO co-occurring with animate $\mathrm{S}_{\mathrm{t}}$. Laubscher (1921: 10) has collected some 13 feminine and masculine occurrences of prophete( $s$, and their patterning would not seem to be obviously incompatible with this hypothesis. ${ }^{22}$

The third phenomenon that finds a natural functional explanation along these lines concerns the OF second masculine declension (cf. 11 above). Recall that this class initially lacked a Nominative-Accusative distinction in the singular; in the plural this distinction had already been accomplished through analogical $-s$ deletion in the Nominative of the pedre type substantives (cf. $11 \mathrm{~b}$ : OF pedre, pedres < VL patre(s), patres). Although this small class was semantically somewhat heterogeneous, its most common representatives were personal substantives:

(15) pedre 'father', fredre 'brother', maistre 'master', gendre 'son-inlaw';

i.e. highly agentive ones, likely to occur in opposite semantic roles. It thus made sense functionally that this whole second masculine declension during the OF period joined the first masculine class. Obviously, this 
analogical innovation of a Nominative Singular $-s$ (thus: pedres, pedre Nominative, Accusative Singular) was the most convenient strategy to weed out its functionally deficient paradigm.

The influence of semantic uniformity on (sub-)paradigmatic coherence was already mentioned, as was the role of natural gender in paradigmatic groupings primarily determined by grammatical gender. The two remaining OF declensions, the third masculine and third feminine classes, evince this influence most perspicuously. Structure and origin of these classes can in part be accounted for phonologically, as far as their properly OF history is concerned; but there also is considerable continuity in their development from $\mathrm{VL}$ - and this is in line with functional requirements. The most notable formal characteristic of the OF third declensions is that they essentially use stem alternation rather than different desinences to distinguish Nominative and Accusative Singular; the plural is built on the oblique stem, with masculines, unlike feminines, lacking an $-s$ in the Nominative (through analogical loss of an historical inflection), just as in the other declensions.

(16) Third masculine declension

a. cuens, conte, conte, contes 'companion, count' uem/on, ome, ome, omes 'man'.

b. niés, nevoút, nevoút, nevoúz 'grandson, nephew' émfes, emfánt, emfánt, emfánz 'child' pástre, pastoúr, pastoúr, pastoúrs 'shepherd' síre, seignoúr, seignoúr, seignoúrs 'sir' chántre, chantoúr, chantoúr, chantoúrs 'singer' emperédre, emperedoúr, emperedoúr, emperedoúrs 'emperor' ábes, abét, abét, abéz 'abbot' lédre, ladrón, ladrón, ladrónz 'robber' Brét/Bréz, Bretón, Bretón, Bretónz 'Breton'.

(17) Third feminine declension suér, seroúr, seroúrs, seroúrs 'sister'.

This raises two not entirely independent questions: How did these stem alternations come about? Which substantives could join these OF declensions?

The main source of these two classes is the VL third declension; more specifically, its masculine and feminine members whose grammatical gender reflects their natural gender, i.e. substantives denoting male and female persons including proper names. In other words: we encounter here a subgroup of those substantives that had already caught our attention as the ones that resisted intraparadigmatic levelling of Nominative and 
Genitive Singular in VL (cf. 3a above). Unlike the second group of nonlevelling substantives in VL, viz. the former neuters in (3b), which became indeclinable in OF (cf. 12), they did not abandon their distinct Nominative and oblique stems in the singular; and it is this continuing conservatism in preserving morphological complexities that are at odds with the analytic 'drift toward the invariable word' which points to a strong functional motivation. The semantic and hence relational potential of nouns denoting persons is by now familiar; they are prototypical possessors and are at the top of the agentivity hierarchy, and these inherent properties inhibit any development that might obliterate their paradigmatic markers of relational distinctions. The conjecture that the 'exceptional' Nominative Singular forms of the OF third declensions owe their survival to the paradigmatic support of the homophonous vocative alone (cf. Rheinfelder, 1967: 24) is even less convincing at this stage originally homophonous vocatives are in many instances unable to prevent analogical changes affecting the Nominative (e.g. in the maistre(s), pedre(s) or the profete(s) paradigms); many other forms do undergo analogical change even though they are also paradigmatically supported; vocatives themselves are subject to change; and there in particular occur vocatives utilizing oblique stems or oblique forms (e.g. signor Vocative Singular, amis Vocative Plural; cf. Laubscher, 1921: 28-35). At any rate, the result of this resistance to morphological change (loss of one stem alternant) is the emergence of a new autonomous declension class (with masculine and feminine sub-paradigms) whose coherence is guaranteed by the semantic uniformity of its members, whereas in CL/VL the third declension was in essence a formally defined class. Formal similarity alone is not a sufficient condition for CL/VL third declension substantives to join this OF class, if they lack the semantic feature / + human/. There are thus only three major aspects of the OF third declensions that fall within the historical domain of OF proper: firstly, the fact that stem alternations are not (yet) abandoned; secondly, the desinence patterns in the plural; and thirdly, the particular phonological shape of the stem alternants. The first two phenomena can be claimed to be due to functional pressure (S-DO distinction), and the third is an automatic epiphenomenon following from the historical (CL/VL) stem alternation patterns. The pertinent OF phonological changes include the diphthongization of stem vowels in open syllables, and different developments of stressed and unstressed vowels, but the segmental and suprasegmental conditions on these changes were already determined by pre-OF paradigmatic forms: stem vowels occurred in open syllables only in the Nominative Singular (comes $>$ cuens, omo $>$ uem), ${ }^{23}$ but not in the Accusative Singular or the Plural after unstressed vowels had been syncopated (comete > 
comte/conte, omene > omne > ome) - which accounts for pattern (16a); a vowel that was unstressed in the Nominative Singular received the main stress in the oblique and the plural forms (népos $>$ niés, but nepóte $>$ nevoút; infans $>$ émfes, but infánte > emfánt; látro > lédre, but latróne $>$ ladrón) - which accounts for pattern (16b)/(17).

The CL/VL third declension is not the only source of the OF third classes, though. A large number of other substantives join these classes, or their Gallo-Roman predecessors (cf. Pope, 1952: 309), by acquiring paradigmatic forms with stem alternation through analogical rather than phonological change. Many of these substantives are of Frankish (Frk) rather than Latin origin; the others derive from Latin, but quite early (sometimes already in VL) restructure their oblique, and occasionally also plural, forms by means of the stem extensions -ón (masculine)/-ain (feminine) (cf. especially Jud, 1907).

(18) Third masculine declension

a. garz, garçón Nominative, Accusative Singular Gui(s), Guión Guén(l)e(s), Ganelón

b. Hue(s), Huón

Charles, Charlón/Charle Pierres, Perrón/Pierre

(19) Third feminine declension

a. Berte, Bertaín/Berte

b. none, nonaín/none 'nun' pute, putain/pute 'whore' ante, antain/ante 'aunt' niece, necién/niece 'niece' taie, taién 'grandmother' Eve, Evaín/Eve Marie, Mariién/Marie

(Frk *wrákjo, *wrakjóne)

(Frk Wído, Widóne) (Frk Wánilo, Wanilóne)

(VL Húgo, Hugóne; Frk Hugo, Hugūn)

(CL Car(o)lus, -um)

(CL Petrus, -um)

(Frk Berta, Bertūn)

(CL nonna, -am)

(CL putida Adj. 'smelling')

(CL amita, -am)

(VL neptia, -am)

(CL Eva, -am)

(CL Maria, -am)

As indicated in (18) and (19), these substantives show some variation, though. There are 'regular' forms without -on/-ain, but these are less common in OF. And with masculines, Nominative and Accusative Singular can occasionally be distinguished by the $-s-\phi$ pattern familiar from the OF first masculine declension, in addition to, or instead of, stem alternation. One can certainly identify morphological models for such third declension substantives with analogical stem alternation (extension): proper names and other masculines with original Latin endings - $o$, -ónis 
(Cáto, Catónis; látro, latrónis), which may have influenced feminines ending in $-a$; Frankish borrowings displayed a quite similar inflectional pattern with $-n$ in oblique and plural forms characteristic of the Germanic weak declension; and learned imitations of CL accusatives in -um/-am may have been another, if much more peripheral, factor. But notice that a genuine explanation of these morphological developments must accomplish more than merely pointing out suitable models for analogical formations; it must also account for the fact that by no means all substantives that for formal reasons could innovate stem alternations or extensions, in fact did analogically acquire such new paradigmatic forms. This latter aspect, the need to specify lexical conditions on eligibility for the OF third declensions, is to be dealt with most plausibly in functional terms. The substantives that do join the OF stem-alternating declension are exclusively personal ones, including proper names ${ }^{24}$ - and it is precisely this type of noun that most urgently requires reliable encoding of the S-DO distinction.

The analogical extension of the Nominative Singular marker $-s /-z$ constitutes the most noticeable kind of interparadigmatic levelling during the OF period prior to the loss of case distinctions (one-case system). We have already had opportunities to comment on several instances of this development - recall the profete $(s)$ type substantives oscillating between the first masculine and feminine declensions, the merger of the OF first and second masculine classes (pedre-pedres), and also third masculine declension proper names like Gui(s); most other substantives with the exception of those in the first feminine declension earlier or later also acquire the Nominative Singular $-s /-z$, and this finally leads to a disintegration of the distinct declension classes, which were essentially based on differences between the various Nominative Singular forms in early OF. This general $s$-extension is well motivated on formal grounds and on grounds of frequency of suitable models: many substantives have preserved an historical s-ending anyway (e.g. CL murus, OF murs; CL Car(o)lus, OF Charles; CL finis, OF finz; CL comes, OF cuens), and one of the masculine classes with an historical $-s$ (first declension) is the most comprehensive one in OF, and thus most likely to attract new members analogically. Functionally, this development is not exactly pointless, but rather exaggerated. The systematic, hence morphologically quite simple, contrast between $-s$ (Nominative Singular) and $-/ \varphi$ (Accusative Singular) allows, or rather necessitates, distinctive S-DO encoding for all substantives (with the exception of those in the first feminine class), rather than for only those whose semantic nature makes this relational distinction particularly advisable. The (near) grammaticalization of the $-s--\phi$ pattern was functionally useful, for example, for the OF third declensions when 
these substantives were finally, and quite gradually, giving up their morphological complex stem alternation by abandoning either their Nominative (20a) or their oblique stem $(20 \mathrm{~b}) .{ }^{25}$

a. garz, garcon-garcons, garcon

compain, compagnon-compainz, compagnon-compagnons, compagnon.

b. emperere(s), empereeur-emperere(s), emperere suer, serour-serour(s), serour-suer, suer.

This particular OF transition from functional to largely grammaticalized S-DO encoding, from semantically natural (at least to a certain extent) declension classes to uniform Nominative and Accusative markers, raises another functional question, which was also alluded to in the introduction to this paper: How is the resulting OF case system with a non-zero (singular) subject desinence and a zero (singular) object desinence to be evaluated from a functional-typological perspective?

In one respect it does not quite conform to typological standards: since $S_{i}$ need not be overtly distinguished from a co-present central relational term, its optimal, and crosslinguistically most common, encoding tends to be zero, unless the case marking of a term co-occurring with a one-place predicate has to indicate whether this term denotes an active or an inactive participant in the event denoted by the predicate, as in languages of the active type (cf. Klimov, 1977) - but OF can hardly be counted among the active-type languages. ${ }^{26}$ Its pattern of identification of transitive and intransitive clause relations, viz. $S_{i}=S_{1} \neq D O$, makes OF an accusativetype language - of a rather unusual kind, though, since in canonical accusative-type languages the DO (non-agent) case is morphologically marked and the $\mathrm{S}$ case morphologically unmarked. The reverse pattern with non-zero marking of the transitive agent and zero marking of the transitive patient, on the other hand, is characteristic of ergative-type languages (cf. Dixon, 1979). We can thus observe in late OF a contradiction between the pattern of relational identification, which is of the accusative type, and the case marking pattern of singular nouns in transitive clauses, which resembles the ergative-type distribution of zero and non-zero marking. One could speculate that this contradiction hastened the demise of the OF nominal case marking system, which happened quite suddenly in the wake of the general $s$-extension. Significantly, the deletion of final $-s$, which ruined the case system, began in Anglo-Norman, i.e. presumably under the influence of a Germanic language that was also drifting towards analyticity but not via a dysfunctional stage like that of later OF. 
The OF pattern of non-zero encoding of subjects is vaguely reminiscent of another ergative-type peculiarity: the lack of consistency. In OF there always remains a residue of unmarked subjects (especially feminines); and most ergative systems are 'split' and display ergative (with marked transitive agent) and accusative (with marked transitive patient) coding patterns alternatively or even simultaneously in a single clause. A common determinant of such ergative splits is the semantic nature of the co-occurring term phrases (cf. Silverstein, 1976), and the choice of accusative- or ergative-type marking within such systems is crosslinguistically anything but arbitrary. Term phrases that rank high on the scale of potential agentivity (i.e. personal pronouns, proper names, other $/+$ human/ substantives, / + animate/ substantives) invariably prefer the accusative pattern, low ranking term phrases (abstracts, inanimates) the ergative pattern. Split ergative languages may vary, however, with respect to the precise position of the cut-off point on the agentivity scale; in highly ergative languages, only the top positions on this scale, first and second person pronouns, qualify for accusative-type marking. The different distributions of zero and non-zero marking in ergative and accusative systems provide the clue to a functional interpretation of such affinities. The basic assumption is that terms may remain morphologically unmarked when occurring in a semantically accustomed role/relation, for reasons of functional economy. Inherently highly agentive nouns are typically agents, and thus require non-zero (i.e. accusative) marking only if occurring as non-agents, whereas nouns with low inherent agentivity typically assume patient or other non-agent roles, and thus require nonzero (i.e. ergative) marking only if occurring as agents. I am not claiming that there is any significant deeper similarity between such split ergative systems and the inconsistent $s$-marking of singular subjects in OF; such typological regularities merely help to point out a functionally problematic aspect of S and DO encoding in late OF. At one stage, parts of the OF case and declension class system, especially in the singular, conformed rather well to that kind of functional requirements that are manifested by certain split ergative systems: the semantically heterogeneous declension classes have non-zero marking for $S_{t}$ (and also $S_{i}$ ) and zero marking for DO, which is the typologically expected pattern for inherently nonagentive nouns; and the semantically homogeneous, i.e. exclusively personal, third declensions, on the other hand, have non-zero DO encoding, viz. the stem extensions or quasi-desinences -on/-ain or -our supplemented by vowel, consonant, and/or stress alternation. The functional stimulus behind this pattern of paradigmatically variable encoding was apparently too insignificant to also influence the plural paradigms or to prevent the generalization of non-zero Nominative Singular marking 
regardless of functional necessities. If the development that leads to a system with consistent non-zero marking of $\mathrm{S}$ and zero marking of DO has to be considered dysfunctional, then the further history of late OF nominal declensions can be interpreted as an attempt to get rid of a functionally unsatisfactory case system. If the Nominative Singular $-s$ was functionally 'bad', it is perhaps no coincidence that it soon disappeared again from the singular paradigms, and was thus able to serve for some time as a pure number rather than case indicator, and, furthermore, that in general accusative forms replaced nominatives in the final system without overt case distinctions. The few nominatives that were able to oust accusative forms come from the OF third declensions (cf. Rheinfelder, 1967: 36-38):

(21) a. ModF prêtre, ancêtre, peintre, traître, chantre, cuistre, Guy.

b. ModF sœur, tante, nièce, Berthe, Ève, Marie, nonne/nonnain, pute/putain;

and in addition to being morphologically unmarked vis $a$ vis the oblique forms, these nominatives in fact were functionally 'good' subject encodings. Since they are also personal nouns but nevertheless preserve dysfunctional non-zero $\mathrm{S}$ forms, the other surviving nominatives, viz. proper names like those in (22a) ${ }^{27}$ and two / + human/ substantives from the first masculine declension (22b):

(22) a. Charles, Georges, Gilles, Jules, Louis (but: Jean, Henri, Pierre, Guillaume ...).

b. fils (CL filius 'son'), queux 'cook' (OF cueus, CL coquos);

probably throw doubt upon this functional explanation, provided the writing of final $-s$ in these cases reflects former phonological reality.

It goes without saying that this paper cannot claim to have given a full account of all paradigmatic developments from CL to OF. Hardly any attention was paid, for example, to nominal paradigms other than those of substantives. The neglect of determiners and adjectives is partly justified in the present context in so far as these optional term phrase constituents apparently played only a minor role in signalling relational distinctions. With regard to pronominal paradigms, the preservation on the whole of distinctive $\mathrm{S}$ and $\mathrm{DO}$ forms would seem to fit in well with functional considerations since personal pronouns rank high on the agentivity scale. What can be claimed, however, is that some of the most noticeable substantival paradigmatic developments involving the encoding of the central grammatical term relations of $\mathbf{S}$ (Nominative), DO (Accusative), 
and A (Genitive), cannot be adequately explained by general principles of analogical change like the following:

Ausgleichsbestrebungen beseitigen das Seltenere zu Gunsten des Häufigeren, das Schwierige zu Gunsten des Einfachen, das Undeutliche zu Gunsten des Klaren. (Rohlfs, 1968: 29).

Even if one succeeds in elaborating a theory of morphological markedness as the appropriate framework for notions such as frequency, complexity, and perspicuity, this would still underestimate the importance of the fact that changes affecting declensional paradigms are to a considerable extent subject to syntactic and semantic conditions. These conditions constitute the domain of functional explanations: paradigmatic change may abandon functionally superfluous, but not functionally vital distinctions; the functional principle may not only prevent paradigmatic changes, it can also induce such changes in order to create the possibility of relational distinction in cases where the semantic nature of a noun makes such distinction advisable. But overt distinction is not the only functional task of relational coding devices; a second task is to guarantee relational identification or recoverability of semantic roles. In general, 'functionally necessary' thus means 'necessary in order to distinguish co-occurring term phrases and to identify their grammatical relation/semantic role in so far as this is not possible on account of their pragmatic or inherent semantic properties'. An important result of the present investigation concerns the relationship between functionally based and grammaticalized coding. Although the relational encoding of each noun may be strictly grammaticalized rather than being variable according to functional needs, languages with several declension classes such as $\mathrm{CL}, \mathrm{VL}$, and OF do not a priori fall outside the scope of a functional principle. As is seen most clearly from a diachronic perspective, it is this type of nominal classification itself which evinces the influence of functional considerations. What the functional principle predicts is that nominal classification and especially re-classification tends to be determined by an interplay of syntactic and semantic factors rather than being entirely arbitrary or determined by some purely formal criterion. Nouns tend to join a declension class that provides for those relational distinctions that are desirable in view of their semantically determined potentiality of occurrence. This is nicely illustrated by the CL/VL/OF third declensions, which afforded optimal $\mathrm{A}$ and S-DO distinctions, and which therefore proved highly attractive only to nouns that are most likely to occur as possessors (A) and possessions (head), or as agents $\left(\mathrm{S}_{\mathrm{t}}\right)$ and patients (DO). Such functionally determined nominal classification is by 
no means a peculiarity of Romance languages. Indo-European neuters are another pertinent example: the range of occurrence of neuters was typically restricted to the role of patient, which rendered the possession of distinct $S_{1}$ and DO forms rather superfluous. Or consider masculine and feminine nouns in certain Cushitic languages (cf. Sasse, 1978). The Cushitic gender categories primarily refer to the semantic notions of social significance (masculine) and insignificance (feminine), and only socially significant entities, essentially persons and higher animals, are likely to occur both as agents and as patients. It is thus in agreement with functional necessities that only the masculine class had distinct paradigmatic S and DO forms. Such parallels are certainly instructive; but only a much more extensive crosslinguisitic survey of paradigmatic change would enable us to determine more precisely the explanatory potentialities and limitations of the functional principle in its application to nominal classification.

Received 4 December 1978

Universität Hannover

Im Moore 21

3000 Hannover 1

F.R. Germany

Notes

* I am indebted to Sarah G. Thomason and Hans-Jürgen Sasse for helpful comments on an earlier version of this paper. Parts of this paper were read at the Autumn Meeting of the Linguistics Association of Great Britain, Sheffield, September 18-20, 1978.

1. This of course presupposes that one has to recognize two distinct relations $S_{i}$ and $S_{1}$. The strongest arguments in favour of this distinction come from ergative languages where $S_{1}$ and $S_{i}$ are often claimed to be encoded, and sometimes also to behave, differently. But this argument is somewhat controversial because it cannot be taken for granted that the transitive agent in an ergative construction in fact is an $\mathrm{S}_{\mathrm{t}}$. (Cf. Plank, 1979b.)

2. See the nominative object in Finnish (Comrie, 1975a). For a different interpretation of this phenomenon see Itkonen (1979).

3. 'Allegedly' because of the proviso mentioned in note 1. It is nevertheless interesting to note that the typological distinction between accusativity and ergativity has recently been a major stimulus of work on the functional basis of grammatical relations (cf. Kacnel'son, 1972: section 2.2; Silverstein, 1976; Dixon, 1979; Comrie, 1978).

4. Examples are taken from the standard handbooks of CL, VL, and OF, especially from those emphasizing the developments towards OF, such as Rheinfelder (1967) and Pope (1952).

5. Some CL third declension substantives also join the VL first declension, e.g. CL potéstas, potestátis > VL potésta, potéstae 'power', and other abstract feminines. 
6. This consideration also makes an a priori possible, but unattested, alternative levelling of stem allomorphy of the type mors, morsis; dens, densis; virtus, virtusis rather undesirable.

7. On these formal grounds, hóspes, hóspitis (2a) might as well have been restructured as hospes, hospis.

8. CL lac, lactis 'milk' is apparently the only levelling exception (VL lactis, lactis) of this subgroup.

9. Laubscher (1921: 28-35), on the other hand, mentions some examples where the oblique form is utilized in vocative function. Similarly Schwan (1966: 152).

10. Since verb agreement refers to the head rather than the $A$ of a complex $S$ term, this can afford a possibility of A-head distinction if, for example, the A is plural and the head singular.

11. If the $\mathrm{S}$ form coincides with the unmarked noun form, i.e. the form used for citation. This is not always the case, though; see again ergative languages such as Eskimo, Burushaski, Mayan, and it is particularly common in languages of this type that we find systematic homophony of $S_{1}$ and $A$ cases (provided the ergative case encodes the $S_{t}$ relation, cf. note 1).

12. For details see Hofmann, 1965: 51, 58; Väänänen, 1956; Rohlfs, 1958: 29ff; Rheinfelder, 1967: 15, 43-45.

13. Which formally derives from the dative in the singular, and the genitive in the plural. See Dardel, 1964.

14. That grammatical relations such as subject have typical semantic and pragmatic properties is of course no particularly original insight. See for example Thomson, 1909; or Royen, 1929: 590: 'Eine Person ist vor allem agens, ein Impersonale vor allem patiens'. And confer also the following statement (on Dravidian languages) from an even earlier functionalist, Bishop Caldwell (1856/1956: 271): ' $\ldots$ the principle that it is more natural for rational beings to act than to be acted upon; and hence when they do happen to be acted upon - when the nouns by which they are denoted are to be taken objectively - it becomes necessary, in order to avoid misapprehension, to suffix to them the objective case-sign'.

15. See especially Westholm, 1899; and also Dardel, 1964; Foulet, 1972: 14-27; Gamillscheg, 1957: 16ff.; Rheinfelder, 1967: 42-3; Väänänen, 1956: 15-18; Wartburg, 1943: 69-70. Modern French still has relics of this construction: fête-Dieu, hôtel-Dieu, la place Mercier, Cours-la-Reine, les fils Michaud.

16. See Foulet (1972: 20): 'le déterminant représente toujours un individu spécifiquement désigné, distinct de tous les autres individus'.

17. This semantic noun classification is relevant also for the DO encoding in another Romance language, Spanish: veo la casa versus veo a mi padre (cf. Wartburg, 1943: 69). In so far as persons are typically agents/ $\mathrm{S}_{t}$, this prepositional marking of persons in the semantically unaccustomed patient role/DO relation makes sense functionally.

18. Unless one is prepared to analyze 's as a postposition on account of its positional versatility in group genitives such as the King of England's grandmother. But then the plural $-s$ could also be claimed to be no longer a proper inflection since it is also separable from its noun (cf. the Attorney Generals etc.).

19. This is not to deny that a substantial number of OF substantives had variable gender; cf. Laubscher, 1921: 1-12, who argues that such gender uncertainties contributed to the eventual breakdown of the entire case system.

20. Analogical Nominative Plural forms portas/portes already occur in Gallo-Roman or even earlier. See Rheinfelder (1967: 17). 
21. This tendency is also attested to by innovations in adjective paradigms; cf. CL Pauper mulier tristis est 'poor woman sad is' > VL paupera mulier trista est. See Rohlfs (1968: 29); Rheinfelder (1967: 49).

22. If it were not for the predictability of the DO relation of un mort on account of the verbal semantics, Elisëus li prophetes resucitat un mort would be a nice example of a functionally necessary $\mathrm{S}_{\mathrm{t}}-\mathrm{DO}$ distinction requiring the masculine form of prophete(s).

23. Provençal lacked this diphthongization: coms, comte; om, ome(n).

24. Feminines also include some proper names for rivers and also animals and allegorical personifications. It is unclear for which functional reasons river names should join this declension.

25. In (20), ' - ' is written instead of ' $>$ ', since these alternatives are often found simultaneously rather than in a definite diachronic sequence.

26. Some accusative-type languages (such as German) may use certain one-place verbs impersonally or personally: mich friert-ich friere 'I (Accusative-Nominative) am cold (third singular-first singular)'; but this pattern is not a sufficient reason to count such languages among the active-type languages. Moreover, this alternation between personal and impersonal constructions did not seem to play a major role in OF at all.

27. The fact that such proper names did not require a plural marker, for which purpose other nouns used the former case-number suffix $-s$, perhaps helped to preserve the $-s$ in the singular in these cases.

\section{References}

Anderson, S. R. (1976). On the notion of subject in ergative languages. In C. N. Li (ed.), Subject and Topic. New York: Academic Press.

Bechert, J. (1979). Ergativity and the constitution of grammatical relations. In F. Plank (ed.), Ergativity: Towards a Theory of Grammatical Relations. London: Academic Press.

Caldwell, R. (1956). A Comparative Grammar of the Dravidian or South-Indian Family of Languages, third edition. Revised and edited by J. L. Wyatt and T. R. Pillai (1956). Madras: University of Madras Press.

Comrie, B. (1975a). The antiergative: Finland's answer to Basque. In R. E. Grossman, L. J. San and T. J. Vance (eds), Papers from the 11th Regional Meeting, Chicago Linguistic Society. Chicago: Linguistic Society.

- (1975b). Direct object case-marking in Uralic languages: an explanatory model. Paper read at the 4th International Finno-Ugric Congress, Budapest.

-1978). Ergativity. In W. P. Lehmann (ed.), Syntactic Typology: Studies in the Phenomenology of Language. Austin: University of Texas Press.

Dardel, R. de (1964). Considerations sur la déclinaison romane à trois cas. Cahiers Ferdinand de Saussure 21, 7-23.

Dik, S. C. (1978). Functional Grammar. North-Holland Linguistic Series 37. Amsterdam: North-Holland.

Dixon, R. M. W. (1979). Ergativity. Language 55, 59-138.

Ekwall, E. (1913). The s-less genitive in early Modern English. In Minneskrift till Axel Erdmann. Uppsala/Stockholm, 53-67.

Foulet, L. (1972). Petite syntaxe de l'ancien français, third edition. Paris: Champion.

Gamillscheg, E. (1957). Historische französische Syntax. Tübingen: Niemeyer.

Gildersleeve, B. L. and Lodge, G. (1895). Gildersleeve's Latin grammar, third edition. London: Macmillan.

Hofmann, J. B. (1965). Lateinische Syntax und Stilistik. (Neubearbeitet von A. Szantyr) München: Beck. 
Itkonen, T. (1979). Subject and object marking in Finnish: an inverted ergative system and an 'ideal' ergative subsystem. In F. Plank (ed.), Ergativity: Towards a Theory of Grammatical Relations. London: Academic Press.

Jud, J. (1907). Recherches sur la genèse et la diffusion des accusatifs en -ain et en -on ( $I^{\text {re }}$ partie). Halle: Karras.

Kacnel'son, S. D. (1972). Tipologija jazyka i rečevoe myšlenie. Leningrad: Nauka.

Keenan, E. L. (1976). Towards a universal definition of 'subject'. In C. N. Li (ed.), Subject and Topic. New York: Academic Press.

Klimov, G. A. (1977). Tipologija jazykov aktivnogo stroja. Moskva: Nauka.

Laubscher, G. G. (1921). The Syntactical Causes of Case Reduction in Old French. Elliott Monographs 7. Princeton University Press. (Kraus Reprint, New York, 1965).

Lehnert, M. (1953). Sprachform und Sprachfunktion im 'Orrmulum' (um 1200). Die Deklination. Berlin: Deutscher Verlag der Wissenschaften.

Li, C. N. (ed.) (1976). Subject and Topic. New York: Academic Press.

Martinet, A. (1979). Shunting on to ergative or accusative. In F. Plank (ed.), Ergativity: Towards a Theory of Grammatical Relations. London: Academic Press.

Plank, F. (1978a). Case syncretism and coding syncretism. In W. U. Dressler and W. Meid (eds), Proceedings of the 12th International Congress of Linguists. Innsbruck: Innsbrucker Beiträge zur Sprachwissenschaft.

-(1978b). Transparent versus functional encoding of grammatical relations: a parameter for syntactic change and typology. Paper read at the 11 th Congress of the Societas Linguistica Europaea, Paris.

-(1979a). Encoding grammatical relations: acceptable and unacceptable non-distinctness. In J. Fisiak (ed.), Historical Morphology. The Hague: Mouton.

-(1979b). Ergativity, syntactic typology, and universal grammar: some past and present viewpoints. In F. Plank (ed.), Ergativity: Towards a Theory of Grammatical Relations. London: Academic Press.

-(ed.) (1979). Ergativity: Towards a Theory of Grammatical Relations. London: Academic Press.

Pope, M. K. (1952). From Latin to Modern French with Especial Consideration of AngloNorman. Phonology and Morphology. Manchester: Manchester University Press.

Rheinfelder, H. (1967). Altfranzösische Grammatik. Zweiter Teil: Formenlehre. München: Hueber.

Rohlfs, G. (1968). Vom Vulgärlatein zum Altfranzösischen. Einführung in das Studium der altfranzösischen Sprache, third edition. Tübingen: Niemeyer.

Royen, G. (1929). Die nominalen Klassifikations-Systeme in den Sprachen der Erde Historischkritische Studie, mit besonderer Berücksichtigung des Indogermanischen. Wien: Anthropos.

Sapir, E. (1921). Language. An Introduction to the Study of Speech. New York: Harcourt. Sasse, H.-J. (1978). Case in Cushitic, Semitic and Berber. Mimeo, Universität München.

Schwan, E. (1966). Grammatik des Altfranzösischen. (Neu bearbeitet von D. Behrens) Darmstadt: Wissenschaftliche Buchgesellschaft (Reprint of the twelfth edition, 1925).

Silverstein, M. (1976). Hierarchy of features and ergativity. In R. M. W. Dixon (ed.), Grammatical Categories in Australian Languages. Canberra: Australian Institute of Aboriginal Studies.

Thomson, A. (1909). Beiträge zur Kasuslehre. Indogermanische Forschungen 24, 293-307.

Väänänen, V. (1956). La préposition latine de et le génitif. Une mise au point. Revue de linguistique romane $20,1-20$.

Wartburg, W. von (1943). Einführung in Problematik und Methodik der Sprachwissenschaft. Halle: Niemeyer.

Westholm, A. (1899). Étude historique sur la construction du type 'li filz le rei' en français. Ph.D. thesis, Uppsala University. 